\title{
College student learning styles and interests in times of pandemic
}

\section{Estilos de aprendizaje e intereses de los estudiantes universitarios en tiempos de pandemia}

ESPERICUETA-MEDINA, Marta Nieves*†, SÁNCHEZ-RIVERA, Lilia, CEPEDA-GONZALEZ, María Cristina and MIRELES-PALOMO, Jaqueline

Universidad Autónoma de Coahuila, Faculty of Science, Education and Humanities

ID $1^{\text {st }}$ Author: Marta Nieves, Espericueta-Medina / ORC ID: 0000-0002-4924-4332, Researcher ID Tomson: T-1500-2018, CVU CONACYT ID: 372705 , arXiv Author ID Espericueta2018

ID $1^{\text {st }}$ Coauthor: Lilia, Sánchez-Rivera / ORC ID: 0000-0001-9468-2599, Researcher ID Tomson: T-1404-2018, CVU CONACYT ID: 613195

ID $2^{\text {nd }}$ Coauthor: María Cristina, Cepeda-Gonzalez / ORC ID: 0000-0003-0676-2412, Researcher ID Tomson: T-16512018. CVU CONACYT ID: 567204

ID $3^{\text {rd }}$ Coauthor: Jaqueline, Mireles-Palomo / ORC ID: 0000-0002-6320-8226, CVU CONACYT ID: 1135843

DOI: $10.35429 /$ JTD.2021.15.5.23.32

Received March 26, 2021; Accepted June 28, 2021

\section{Abstract}

Learning styles are different methods that students use to learn, influenced by different factors that modify this learning, such as motivation, study methods, and the student's attitude, among others. This work focuses on the learning styles and interests of the university student, the main objective is to identify the factors that affect the learning style and interests of higher education students in times of pandemic. The methodology was integrated from the research instrument that generated information for the explanation of this issue, its focus being quantitative, in addition to the theoretical value based on the integration of theories. The research was carried out with a sample of 1,412 higher education students. The instrument was designed considering 160 variables, 10 signal variables and 150 variables of learning styles and interests divided into several subdimensions, the STATISTIC program was used for statistical treatments based on frequencies, percentages, comparison and factorial analysis. Among the main research results it was found that women attend college because they have an interest in learning and preparing to successfully achieve their goals, and not just because of a college degree, unlike men. In addition, students are clear that experience is essential to develop the knowledge acquired, having a real experience of what the world of work is, venturing into them and at the same time being learning. The intervention proposal is to promote in the universities that from the first semesters or semesters the student is allowed to have a real experience in the labor field about his career.

\begin{abstract}
Resumen
Los estilos de aprendizaje son diferentes métodos que utilizan los estudiantes para poder aprender, en los cuales influyen diferentes factores que modifican este aprendizaje como la motivación, los métodos de estudio, la actitud del alumno, entre otros. El presente trabajo tiene como ejes los estilos de aprendizaje y los intereses del estudiante universitario, el objetivo principal es identificar los factores que inciden en el estilo de aprendizaje y los intereses de los estudiantes de educación superior en tiempos de pandemia. La metodología se integró a partir del instrumento de investigación que generaba información para la explicación de este tema, siendo su enfoque de corte cuantitativo, además que el valor teórico radico en la integración de teorías. La investigación se realizó con una muestra de 1412 estudiantes de educación superior. El instrumento se diseñó contemplando 160 variables, 10 variables signalíticas y 150 variables de los estilos de aprendizaje e intereses dividido en varios subdimensiones, se utilizó el programa STATISTIC para los tratamientos estadísticos a partir de frecuencias, porcentajes, comparación y análisis factorial. Entre los principales resultados de investigación se encontró que las mujeres asisten a la universidad porque tienen interés en aprender y prepararse para lograr sus metas con éxito, y no solo por obtener un título universitario, a diferencia de los hombres. Además, los estudiantes tienen en claro que la experiencia es fundamental para desarrollar los conocimientos adquiridos, teniendo una experiencia real de lo que es el mundo laboral, aventurándose en ellas y al mismo tiempo estar aprendiendo. La propuesta de intervención es promover en las universidades que desde los primeros semestres o cuatrimestres se le permita al estudiante tener una experiencia real en el campo laboral sobre su carrera.
\end{abstract}

Interés, Estilos de Aprendizaje

Citation: ESPERICUETA-MEDINA, Marta Nieves, SÁNCHEZ-RIVERA, Lilia, CEPEDA-GONZALEZ, María Cristina and MIRELES-PALOMO, Jaqueline. College student learning styles and interests in times of pandemic. Journal of Technological Development. 2021. 5-15: 23-32

\footnotetext{
* Correspondence to Author (email: mnieves@uadec.edu.mx)

$\dagger$ Researcher contributing first author
} 


\section{Introduction}

Since ancient times, the human being began his learning process spontaneously and naturally with the purpose of adapting to his environment, in this way he has been surviving the different changes that have occurred in the world. Learning styles are all those cognitive and physiological traits by which students perceive and interact within the learning processes That is why the present research aims to make known the learning strategies and interests that move the university student in these times of pandemic that he is living.

\section{Justification}

This research is important in consideration of the explanation that will be obtained about how the learning styles and interest of the university student intervene in their academic performance Students from the different universities in Mexico will be the main beneficiaries; in consideration that teachers will be able to distinguish how it affects the learning styles and interests of the university student to implement strategies that impact their academic performance in times of pandemic.

The theoretical value of this research lies in the integration of bibliographies referring to the subject and the instrument. On the other hand, the methodological value is integrated from the research instrument that will generate information to explain these phenomena. The viability of this project lies in the fact that the research contents respond to needs that impact society and the educational environment every day.

\section{General objective}

Identify the variables that make up the learning styles and interests of higher education students in times of pandemic.

\section{Research questions}

- How often is the male gender in the sample?

- What percentage of students is 21 years old?

- What is the comparison that exists between the students who study by semester and semester with respect to the manual of impressions?
- What are the variables that make up the study method?

- What are the variables that make up the printing manual?

\section{Theoretical framework Learning styles}

Learning styles are all those cognitive and physiological traits by which students perceive and interact within the learning processes. However, this concept has evolved over time.

Jester, (2000), defines learning styles as "the way that students prefer to learn and that have nothing to do with intelligence, but with the way the brain works more efficiently to learn new information."

Later, (Cazau, 2004) defines the term Learning Style "to the fact that each person uses their own method or strategies to learn. Although the strategies vary according to what one wants to learn, each one tends to develop preferences or global tendencies that define a Learning Style. There is talk of a general trend, since, for example, someone who is almost always auditory can in certain cases use visual strategies".

However, 5 years later the learning style was established as a set of biological and maturation ally-imposed characteristics that make the same teaching method effective for some learning styles, which is like a personal stamp. Learning styles are determined by the biological characteristics of each person and by the estimate received, (Plan PROA, 2009).

Gallego, (2010), mentioned that learning styles are defined as cognitive, affective and physiological traits that serve as relatively stable indicators of how individuals perceive, interact and respond to their learning environments Therefore, conceptually learning styles they are understood as personal variables that, halfway between intelligence and personality, explain the different ways of approaching, planning and responding to the demands of learning. Learning styles have become elements of great importance to promote quality teaching. (Tapias, 2018) mentioned that Learning Styles are cognitive, affective and physiological traits that serve as relatively stable indicators of how students perceive, interact and respond to their learning environments. 
The Learning Styles construct arises with the purpose of jointly examining the cognitive and personality aspects that participate in all learning situations (Sternberg cited by Fernández, 2020). According to Keefe, Learning Styles are defined as the cognitive, affective and physiological qualities that students put into play when learning (Keefe cited by FreibergHoffmann, 2020)

Finally, (Pérez, 2021) refers to the fact that a learning style consists of a series of personal characteristics with which you are born and that you develop as you grow up. Determine, among other things, through which activities and senses you tend to absorb information more easily; whether through sight, sound, touch, speech, note-taking, or a combination of these. There are three major systems to mentally represent information, the visual representation system, the auditory and the kinesthetic. Most of us use one more than the other, because they develop differently in each one of us and have their own characteristics.

The visual representation system tends to be the dominant representation system in most people. It occurs when one tends to think in images and relate them to ideas and concepts. The people who are information by following and recalling an oral explanation. And Kinesthetic Representation System is about learning related to our sensations and movements. In other words, it is what happens when we learn more easily by moving and touching things, such as when we walk when reciting information or doing an experiment manipulating laboratory instruments.

\subsection{Learning styles in times of pandemic}

In recent years, where the entire world situation has been affected by the pandemic related to COVID 19, various studies have been carried out that seek to investigate the factors that impact the learning styles and interests of the student, in that sense for Trucco and Palma (2020) the massification of connectivity based on the mobile Internet and the increase in more accessible digital devices, policies have redirected their efforts to the formation of digital skills of students.
For many women and girls, confinement means an exacerbation of the unpaid care workload, which in turn has consequences for their learning. According to the International Labor Organization (ILO, 2018) For Miguel Román, J. A. (2020) in a study carried out concludes that:

"Teachers are in a state of learning and rupture, as are students; Both actors warn that it is necessary to develop self-learning, autonomy and socio-emotional skills. In sum, it is essential to rethink that the roles of each of the actors in the training process in higher education require a paradigm shift; transform our limitations into strengths and appropriate each of our responsibilities. Today more than ever, in times of pandemic, education must take a complex approach, since the totality often exceeds the sum of its parts. It is therefore necessary to educate for uncertainty"

Likewise, for Enríquez Vázquez Larisa and Hernández Gutiérrez Myrna (2020) in relation to learning, they consider that the participation that the teacher should have in, in addition to the traditional cognitive dimension, the metacognitive, social, and action-oriented dimensions is clear. . But, above all, in the context generated by covid-19, in the affectiveemotional dimension, since the current emergency shows the need for accompaniment and listening.

\subsection{Learning styles in relation to academic performance}

Most researchers agree that academic performance is the result of learning produced by the didactic and pedagogical interaction of the teacher and student. For (Pizarro, 1985), academic performance is "a measure of the responding or indicative capacities that express, in an estimate, what a person has learned as a consequence of a process of instruction or training"; while (Martínez \& Otero, 2007) considers that academic performance is "the product that students give in schools and that is usually expressed through school grades". (García, 2018) It determined that learning styles are a factor that significantly influences the academic performance of students; But you can't just blame learning styles; On the contrary, there is a diversity of factors that influence academic performance, among them are: socioeconomic, teaching methodologies, previous competences, motivation.

ESPERICUETA-MEDINA, Marta Nieves, SÁNCHEZ-RIVERA, Lilia, CEPEDA-GONZALEZ, María Cristina and MIRELES-PALOMO, Jaqueline. College student learning styles and interests in times of pandemic. Journal of Technological Development. 2021 
It is clear that the students' preferred style is the reflective one characterized by being investigative, analytical, working assertively and as a team, managing to understand the data analyzed in a systemic way, leading them to solve various problems by applying the knowledge learned in an integrative way.

Estela (2021) in an investigation carried out in which I compare the learning styles in students of the civil engineering and agroindustry engineering career of a University of the city of Chota, Cajamarca; During the course of the year 2021, he found that the results showed that in general there are no significant differences regarding learning styles according to gender in this context.

García, (2017) mentions that the relationship that exists between the Learning Styles and the Academic Performance of the students of the courses of the construction area of the FIC-UNI, 2017, was tested with the statistical inference that there is no relationship between the Learning Styles and Academic Performance of the students under study, in the academic year, 2017.

Gallo, (2018) determined the relationship between Learning Styles and Academic Performance of Economic Engineering students from a public university. It was a quantitative investigation, at a descriptive level, with a nonexperimental cross-sectional design. The population was 470 and the sample of 92 students enrolled in the 2017-1 cycle. The CHAEA questionnaire was used, which consists of 80 items. It was found with the descriptive and inferential statistics that there is no significant correlation between the theoretical learning style and the academic performance with $\mathrm{p}$ value $=$ 0.384 . There was also no significant relationship between the reflective style $(\mathrm{p}=0.371)$, pragmatic $(\mathrm{p}=0.438)$ and active style $(\mathrm{rp}=$ 0.002 ) since the significance was greater than 0.05 in all cases.

Clump and Skogsberg (2003) point out that during the development of the ILP (Inventory of Learning Processes), Schmeck et al. (1977) found no significant differences in learning styles between men and women.

\section{ILP-R Instrument}

The Learning Process Inventory Id. The first measure of learning styles that had been developed in the context of cognitive psychology and derived from information processing theories. The objective of this article is to determine the validity of the Spanish adaptation of this questionnaire. Almost 30 years have endorsed this instrument since the appearance of the first version in the United States. The ILP was constructed from factor analysis applied to a survey of a sample of students on studies describing activities and assumptions based on cognitive psychology, such as memory and information processing. Factor analysis uncovered four factors called deep processing, elaborative processing, data retention, and study method.

Ruiz, Fuensanta Cerezo, \& Manuel Esteban, (1996), mention that both deep and elaborative processing refer to learning strategies that require reflection. Although they differ in the personal way of facing the task of learning: Deep processing is more abstract, logical and theoretical, it is what we could call "academic style", while elaborative processing is more experimental and self-expressive. Data Retention is geared toward the retention of units of information necessary to successfully perform multiple-choice tests.

The Study Method is composed of those skills that are usually applied when studying a topic, such as the use of a library or dictionary, underlining, collecting notes, ordering notes, etc. Studies on the validation of the questionnaire showed significant correlations between learning strategies and personality variables. For example, Schmeck and Ribich (1978) found that individuals who scored high in deep processing (abstract and theoretical) were able to use conformist or independent thinking depending on the situation, while those who did so in data retention and method. of study tended to act only by the conformist route. Similar relationships were found between information processing styles and personality, especially with Selfefficacy, Self-esteem, Self-affirmation, Locus of control, Anxiety and Fear of failure. In several cases, the personality variables acted as mediators of the control of anxiety and fear of failure. In other cases, the personality variables acted as information processing and the current performance variables. 
Thus, for example, Schmeck and Spofford (1982) found that moderate neuroticism correlated with the tendency to use deep processing and that a moderate degree of fear of failure correlated with paying more attention to superficial aspects of the information. In 1988, Schmeck added two new dimensions of effectiveness: thinking and memorization and two others on cognitive style: serial and holistic. Despite these variations, certain consistencies emerge in all applied versions.

Personality and cognitive process items are grouped consistently, which means two ways of producing a hierarchical model of individual differences in behavior and attitudes for learning: academic self-efficacy, self-esteem, self-assertion and motivation appear as dimensions. not cognitive or personality. Deep processing, elaborative, impulsive and the study method appear as cognitive or learning dimensions. (Manuel Esteban, Cecilia Ruiz, \& Fuensanta Cerezo, 1996)

The questionnaire contains the aspects of the phenomenon that are considered essential; It also allows us to isolate certain problems that interest us mainly; reduces reality to a certain number of essential data and specifies the object of study.

\section{Methodology to be developed}

When the primary research question is established, one begins to inquire about the bibliography that supports the primary initiative of this work, the goals, questions of inquiry and inquiry conjecture are developed, which are consistent with the primary and complicated changes of the instrument to use.

It should be noted that a standardized tool from Spain was used and certain expressions were adapted that have the possibility of causing confusion in the subjects to whom the survey was applied, this in order to avoid biases. The measurement of the sample was concluded based on pre-established criteria that indicated the need to exercise the instrument on 1412 people, with which the instrument was adapted to a digital version given the social conditions in which this work is carried out.
In such a way that the application has been made through a Google form, which allowed to skip the data capture to go directly to its procedure. The instrument consists of 2 sections: the first contains the general data where changes are observed: Age, Gender, Location where they study, Type of studies, currently working, Average, has worked, University where they carry out their studies. The third section corresponds to the magnitudes of Learning styles and various interests of them with subdimensions that are made up of 150 items that are measured on a scale from 1 to 6 .

Once organized in a concentration matrix, the data obtained are given statistical treatment to explore the results where a Cronbach's alpha of 0.91 is received. In addition, the information is processed through descriptive statistical studies (frequencies and percentages), comparative (Student's $t$ test for independent teams) and with the Integrational (with exploratory factorial research); It is a quantitative, synchronous and transversal investigation of an exploratory and detailed type.

\section{Result}

\section{Descriptive Analysis}

\subsection{Frequencies and Percentages}

To analyze the values of the signal variables that represent the sample studied, an analysis of frequencies and percentages applied to the subjects under study is carried out, the total of which corresponds to a value $n$ of 1412 .

In the analysis of the gender variable, results were obtained where it is observed that $64.38 \%$ of the population corresponds to the female gender, while $35.06 \%$ corresponds to the male gender.

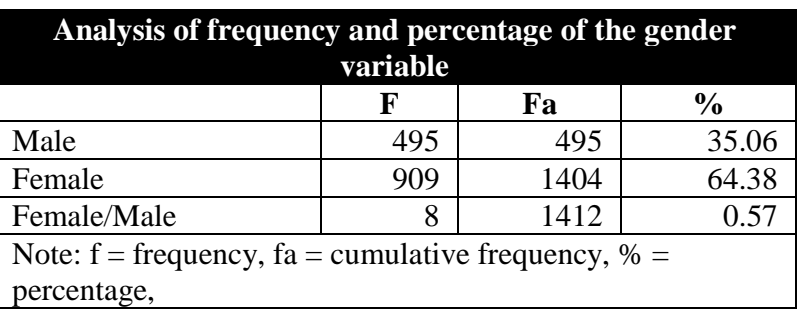

Table 1 Analysis of frequency and percentage of the gender variable

Source: Own Elaboration 
Where their age range is from 14 to 52 years, their average being 22 years with $13.17 \%$. In addition, $78.61 \%(\mathrm{n}=1110)$ of the studied population carried out their studies in the city of Saltillo.

In the results obtained in the variable university career, with a total of 179 majors it is shown that the most outstanding are Lic. In psychology with $11.69 \%(\mathrm{n}=165)$, Lic. In educational sciences with a percentage of $11.40 \%(\mathrm{n}=161)$ and Industrial Engineering with a percentage of $8 \%(n=113)$.

\section{Comparative Analysis}

\subsection{Student's t for independent samples}

Next, a comparative analysis of the variables that make up the phenomenon of study is presented, carried out through the Student's t test procedure for independent samples, with a confidence level of $95 \%$. The statistical program STATISTICA was used to analyze the significant differences between gender, age, state where they study, city where they study, educational institution, career, modality, average, current job and previous job; which were contrasted against the dimensions of the investigation.

A study of means is carried out through the Student's $t$ test for independent samples, defining the working hypothesis $\mathrm{H} 1=$ "there are significant differences between the comparison groups". The results of interest for the work are those in which the Student's t test indicates the existence of significant differences between the comparison groups.

The results of interest for the work are those in which the Student's $t$ test indicates the existence of significant differences between the comparison groups. The readings and inferences corresponding to the different comparative analyzes that are of interest to the study are presented below. It can be observed that, according to comparison analysis of the means of the variables, women have greater enthusiasm for learning, prepare for exams and carry out their tasks appropriately, always seeking success in what they do, knowing that the only way to meet your goals is by taking an interest in their learning, unlike men.
Thus, it is inferred that women attend college because they have an interest in learning and preparing to achieve their goals successfully, and not just because of a college degree, unlike men.

According to the comparative analysis of the means of the variables, it is observed that women use different techniques, such as diagrams, summaries, and notes, so that their learning is better, and they investigate on their own questions that they do not understand the first time. It is inferred that women look for a way that their learning is of better quality through didactic supports where they express their ideas, unlike men. Likewise, it is observed, according to the comparative analysis, that women pay more attention in class, however, they forget the things they learn faster than men. From the above, it can be inferred that, although men pay less attention in class, they are less likely to forget what they learn than women.

It was found that students who are 21 years old like to read articles that have to do with their studies to obtain more knowledge and, in addition, they reflect on what they have learned in class to successfully elaborate their tasks, unlike those who are 23 years old. Among the variables that measure the study method, there are significant differences between the ages of 21 and 23 in the following: Students who are 21 years of age strive to get good grades in their exams, relying on diagrams made on material from class, unlike 23-year-old students.

Therefore, it is inferred that students with the age of 23 do not worry so much about studying to get good grades in their exams, since they remember much of the content seen, unlike students with 21 years. Students who have a 93 average is because they are interested in their personal training and attend university for the pleasure and desire to learn, in addition to having clear goals and maintaining a positive attitude unlike students who have a 75 average. Based on the above, it is inferred that students who have a 75 average is because it is difficult for them to study and they prefer to spend more time with friends than studying, unlike students who have a 95 average. 


\section{Integrational Analysis 3.1 Exploratory factorial}

With the intention of affirming that there are factors that describe the learning strategies and appropriation of knowledge present in higherlevel students from the elements that make up their learning styles and interests, an exploratory factorial analysis was carried out, in which it was considered the Kaiser criterion. As an extraction method, the Maximum Likehood was used; with normalized Varimax rotation as it is It is integrated with variables that support the paradigm proposal. We work with an error level $\mathrm{p} \leq 0.001$ and a confidence level of 95

$\%$ and a value $r=0.33$.

The study shows the existence of 12 factors, which $44 \%$ explain the objective reality of the phenomenon under study. Next, six factors will be read, according to the sedimentation graph where the inflection point of the dimensions of global motivation, study method and manual of impressions is presented. The first factor was named personal interest. In the factor, it is observed that students who are within said factor stand out for having self-efficacy because they think quickly and without making mistakes, since, in most of their exams they obtain the correct answers, in addition, they have the ability to remember small details that are of great importance to them when studying.

They are motivated by wanting to improve themselves personally, therefore, they attend university for their own pleasure, always having an enthusiastic attitude and taking the fun side of learning, performing their tasks correctly and with determination to be able to achieve their established goals, doing it with pleasure and to be as successful as possible in their lives. Likewise, they are students with an outgoing personality, who are not afraid of being criticized by other people, always expressing their ideas, and contradicting other people's opinions when something does not seem to them. The study method used by these students are techniques and strategies of summarizing information, making it more concrete and accurate, making diagrams and graphs as study support when studying for their exams, investigating the material seen in class and when something does not show them. It is clear they investigate on their own until discovering the meaning, therefore, their vocabulary is increasingly enriched with new words, in addition, they raise their ideas and order them to be clear about the learning.
They are students who when a problem is presented to them always look for their solution, using all the alternatives that are within their reach, looking for scientific explanations, comparing theories for a better resolution and relating ideas, in addition, they are supportive students than when someone else has some problem and is having difficulty solving it, offer your help without expecting anything in return.

They are clear that experience is essential to develop the knowledge acquired, having a real experience of what the world of work is, venturing into them and at the same time being learning without forgetting the values that the family instills to always be an honest person. Likewise, they have their system to remember learning or situations that serve them, associating subject words.

They have a very good imagination, they are intuitive, when they have an idea in mind they tend to involve external ideas in order to relate them, relying on images that help them to better manage and clarify points of view. They always use reason and logic to solve their doubts and problems, attending to complicated situations through steps, so that everything goes in order and as expected.

They are rote students, where they tend to repeat and repeat everything seen in class to have a better acquisition of knowledge, always relying on their teacher as a guide. In factor 2 named Disinterest, it can be said that students who are within this factor stand out for having difficulty in their learning, since, they do not organize themselves to carry out their activities, they have problems remembering topics seen, they tend to get confused, they are Nervous people are easily distracted, and do not have the ability to relate ideas and solve problems, therefore, they have difficulty studying in their exams.

They do not know how to make a critical evaluation, or differentiate between logical aspects. They are students with poor memory, and for the same reason they get bored easily in classes and settle only for what they come to understand without inquiring on their own, they are irresponsible since they are not interested in studying to get good grades on their exams. They have low self-esteem, as they are affected when people criticize them and they get nervous when they do. 
They need professional guidance. In factor 3, named Efficient memory, it is said that students who are within this factor are dependent, do not have their own decisions and always have to help them choose other people, as well as they believe that success is a matter of luck. However, they are organized students who distribute their activities in schedules so that everything goes as it should, they are learning by rote, since they have a perfect memory and remember any data that has been presented to them. They are responsible people who always study for their exams, do their homework, and are attentive in class.

In factor 9, named Irresponsibility, it is said that the students who are within this factor are people who do not use the library or the dictionary so much, they do not like to read or reflect on what they read, they are in university just to get a professional title without caring what they can learn, they do not intend to apply the knowledge they acquire, they are dependent people, they have to be told what to do and how to do things so as not to have complications, and they like to go out with friends more than study for their exams.

In factor 10, named Learning strategies, it is read that students within this factor use different study methods for the presentation of their exams, they make use of a list of questions and answers that possibly come within the exam, they repeatedly read the They viewed content, they make summaries, diagrams and graphics of the material worked on in class, they organize themselves in their schedules and they repeatedly review their notes relating them to their ideas.

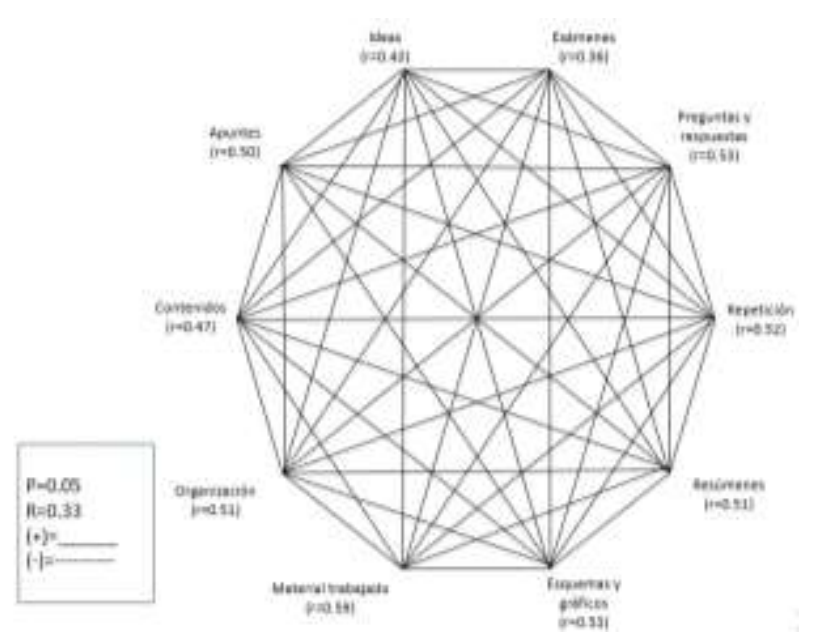

Figure 1 Exploratory factor analysis, Factor 10. Person imagel
In factor 11, named Interest in learning, it is observed that students who are within this factor go to university because they are interested in learning new and interesting things, in addition, they are clear about their goals knowing that they can be successful academically. They have a positive attitude, always willing to learn and carry out the activities assigned to them.

\section{Conclusions}

Women attend college because they have an interest in learning and preparing to achieve their goals successfully, and not just because of a college degree, unlike men.

Women look for the way that their learning is of better quality through didactic supports where they express their ideas, unlike men.

Although men pay less attention in class, they are less likely to forget what they learn than women.

21-year-olds have a greater interest in reading and reflection, and are more responsible for their homework unlike 23-year-old students.

23-year-old students do not worry as much about studying to get good grades on their exams, since they remember much of the content seen, unlike 21-year-old students.

The students who pursue their career in the city of Saltillo are not interested or clear about their goals, so they do not enjoy their learning, unlike students in the city of Monterrey.

Students who have a 75 average is because it is difficult for them to study and they prefer to spend more time with friends than studying, as opposed to students who have a 95 average.

Students of personal interest are motivated by wanting to improve themselves, therefore, they attend university for their own pleasure, always having an enthusiastic attitude and taking the fun side of learning, performing their tasks correctly and with determination to be able to achieve their established goals. 
Students who have disinterest are noted for having difficulty in their learning, since, they do not organize themselves to carry out their activities, they have problems remembering topics seen, they tend to get confused, they are nervous people, they lose concentration easily, and they do not have the ability to relate ideas and problem solving, so they have difficulty studying on exams.

Students with effective memory are organized who distribute their activities in schedules so that everything goes as it should, they are rote learning, since they have a perfect memory and remember any data that has been presented to them.

Students who are irresponsible are people who do not use the library or the dictionary so much, they do not like to read or reflect on what they read, they are in university just to obtain a professional degree without caring what they can learn, they do not pretend to apply knowledge They acquire, they are dependent people, they have to be told what to do and how to do things so as not to have complications, and they like to go out with friends more than study for their exams.

Students who use learning strategies use different study methods for the presentation of their exams, make use of a list of questions and answers that may come within the exam, repeatedly read the contents seen, make summaries, diagrams and graphics of the material studied in class, they organize their schedules and repeatedly review their notes relating them to their ideas.

Students who are interested in learning at university because they have an interest in learning new and interesting things, in addition, they are clear about their goals knowing that they can be successful academically.

\section{Discussion}

In the results it was found that students use didactic methods such as diagrams, graphs, summaries, notes and repetition of words, involving their ideas and comparing them with others to have a better learning, for which they agree with the ( Raco D-Study, 2020) where it says that a learning style is the way in which students respond to or use stimuli in the learning environment, that is, the educational conditions under which a student is more likely to learn.
As mentioned, in the results it was found that most of the students have different ways of learning, some use didactic methods, others memorization, others when viewing images, therefore, we agree with the author, (Pérez, 2021) that he mentions through activities and senses we tend to absorb information more easily; whether through sight, sound, touch, speech, note-taking, or a combination of these.

\section{Proposals}

Implement in universities that students have the opportunity to have work experience from the first semesters or semesters so that they can become familiar with real experiences.

Train teachers periodically so that they have the tools and knowledge necessary to teach their students with the various forms of teaching, this in order for each of the students to acquire knowledge in their own way.

Implement workshops where students express their ideas and learn to relate them to external ideas for greater learning.

\section{References}

Cazau. (2004). Estilos de aprendizaje. Obtenido de Estilos de aprendizaje.

Esteban, M., Ruiz, C., \& Cerezo Ramírez, F. LOS ESTILOS DE APRENDIZAJE Y EL RENDIMIENTO EN CIENCIAS SOCIALES Y EN CIENCIAS DE LA NATURALEZA EN ESTUDIANTES DE SECUNDARIA. Anales de Psicología / Annals of Psychology, 12(2), 153166. Recuperado a partir de https://revistas.um.es/analesps/article/view/305 11

Enríquez Vázquez, Larisa y Hernández Gutiérrez Myrna (2021 marzo- abril ) Alumnos en pandemia: una mirada desde el aprendizaje autónomo. Revista Digital Universitaria (RDU), $22(2)$

Estela Rojas, W. G. (2021). Estilos de aprendizaje según género en estudiantes de ingeniería civil e ingeniería agroindustrial de una universidad de Chota, 2021. 
Fernández Da Lama RG. Problemáticas actuales del sistema educativo superior: análisis desde los estilos de aprendizaje. Ajayu Órgano de Difusión Científica del Departamento de Psicología UCBSP. marzo de 2020;18(1):78101

Freiberg-Hoffmann A, Abal F, FernándezLiporace M. Cuestionario Honey-Alonso deEstilos de Aprendizaje: Nuevas evidencias psicométricas en población argentina. ActaColombiana de Psicología. 2020;23(2):32838

Gallego, (2010). evolución de los estilos de aprendizaje. Revista estilos de aprendizaje, 1-10.

GALLO, R. A. (2018). RELACIÓN ENTRE LOS ESTILOS DE APRENDIZAJE Y RENDIMIENTO ACADÉMICO DE LOS ESTUDIANTES DE INGENIERÍA ECONÓMICA EN UNA UNIVERSIDAD PÚBLICA DE LIMA. LIMA, PERÚ.

García, A. E. (28 de JUNIO de 2018). ESTILOS DE APRENDIZAJE Y RENDIMIENTO ACADÉMICO. Riobamba, Ecuador.

GARCÍA, L. A. (2017). ESTILOS DE APRENDIZAJE Y RENDIMIENTO ACADÉMICO DE LOS CURSOS COMPRENDIDOS DENTRO DE LA LÍNEA DE CONSTRUCCIÓN. Lima, Perú.

Jester. (2000). Desarrollo. Obtenido de Desarrollo.

Martínez, \& Otero, V. (2007). Los adolescentes ante el estudio. Causas y consecuencias del rendimiento académico. Madrid: Fundamentos.

Miguel Román, J. A. (2020). La educación superior en tiempos de pandemia: una visión desde dentro del proceso formativo. Revista Latinoamericana De Estudios Educativos, 50(ESPECIAL), 13-40. https://doi.org/10.48102/rlee.2020.50.ESPECIA L. 95

OIT (Organización Internacional del Trabajo) (2018), El trabajo de cuidados y los trabajadores del cuidado para un futuro con trabajo decente, Ginebra
Pérez, L. (5 de enero de 2021). UNITEC Blog. Obtenido de UNITEC Blog: https://blogs.unitec.mx/vidauniversitaria/estilos-de-aprendizaje- visualauditivo-y-kinestesico-cual-eres

Pizarro, R. (1985). Rasgos y actitudes del profesor efectivo. Tesis de Maestría. Santiago de Chile: Pontificia Universidad Católica de Chile. Plan PROA. (12 de enero de 2009). Modelos de orientación e intervención psicopedagógica. Obtenido de Modelos de orientación e intervención psicopedagógica: https://salircorriendo.blogia.com/2009/0 11201estilos-de-aprendizaje.php

Schmeck, R. R. y Ribich, F. (1978). Construt validation of the Inventory of Learning Processes. Applied Psycho logical Measurement, 2, 551-562.

Schmeck, R. R. y Spofford, M. (1982). Attention to semantic versus phonetic verbal attributes as a function of individual defferences in arousal and learning strategy. Contemporary Educational Psychology, 7, 312-3

Tapias, M. G. (2018). Dialnet. Obtenido de Dialnet:

file:///C:/Users/Palomo/Downloads/Dial netEstilosDeAprendizajeEstrategiasParaEn senar6383448.pdf 